Jurnal SPORTIF: Jurnal Penelitian Pembelajaran

Vol. 6 No. 2, Agustus 2020, pp. 316-331

doi) https://doi.org/10.29407/js_unpgri.vi.13712

\title{
Efek pemberian jus semangka kuning terhadap tekanan darah, kadar asam laktat, dan daya tahan anaerobik setelah aktivitas anaerobik
}

\section{The impact of yellow watermelon juice intake after performing anaerobic activity on blood pressure, lactic acid levels, and anaerobic endurance}

\section{Afif Rusdiawan ${ }^{1}$ dan Ahmad Ilham Habibi ${ }^{2}$}

1,2Pendidikan Jasmani Kesehatan dan Rekreasi, IKIP Budi Utomo Malang, Jalan Simang Arjuno No.14 B Kauman-Klojen, Malang, 65119, East Java Province, Indonesia

Received: 8 January 2020; Revised: 4 April 2020; Accepted: 5 June 2020

\begin{abstract}
Abstrak
Tujuan dari penelitian ini adalah untuk mengetahui efek pemberian jus semangka kuning terhadap penurunan tekanan darah, kadar asam laktat, dan peningkatan daya tahan anaerobik setelah aktivitas anaerobik. Jenis penelitian ini adalah penelitian eksperimen dengan desain randomized group pre test and post test design. Subyek penelitian menggunakan atlet bulutangkis putra PBSI Jombang yang dibagi secara acak ke dalam kelompok control (K1) dan kelompok perlakuan (K2) yang masing-masing terdiri dari 18 orang coba. Kelompok kontrol diberikan sirup tanpa gula sebanyak $350 \mathrm{ml}$, sedangkan kelompok perlakuan diberikan jus semangka sebanyak $350 \mathrm{ml}$. Aktivitas anaerobik dilakukan dengan lari sprint 300 meter. Pengukuran tekanan darah, asam laktat, dan daya tahan dilakukan 3 kali (pretest, posttest 1 dan posttest 2). Hasil uji t 2 sampel bebas menunjukkan bahwa terdapat perbedaan yang signifikan pada variabel tekanan darah sistole (TDS) nilai $p=0,023$ dengan rerata $K 1 \quad 129,11 \pm 6,55 \mathrm{Mm} / \mathrm{Hg}$ dan $\mathrm{K} 2$ $125,67 \pm 4,77 \mathrm{Mm} / \mathrm{Hg}$, tekanan darah diastole (TDD) nilai $\mathrm{p}=0,019$ dengan rerata $\mathrm{K} 178,72 \pm 4,61 \mathrm{Mm} / \mathrm{Hg}$ dan $\mathrm{K} 276,22 \pm 4,86 \mathrm{Mm} / \mathrm{Hg}$, kadar asam laktat nilai $\mathrm{p}=$ 0,006 dengan rerata $\mathrm{K} 14,59 \pm 0,97 \mathrm{mMol} / \mathrm{L}$ dan $\mathrm{K} 2$ 2,81 $\pm 0,73 \mathrm{mMol} / \mathrm{L}$ serta daya tahan anaerobik nilai $\mathrm{p}=0,012$ dengan rerata $\mathrm{K} 17,13 \pm 0,74$ watt/sec dan $\mathrm{K} 2$ $6,08 \pm 0,80$ watt/sec. Hasil tersebut dapat disimpulkan bahwa pemberian jus semangka kuning (citrullus vulgaris schard) dapat menurunkan tekanan darah dan kadar asam laktat serta meningkatkan daya tahan anaerobik setelah aktivitas anaerobik.
\end{abstract}

Kata kunci: aktivitas anaerobik, jus semangka, tekanan darah, asam laktat, daya tahan.

\begin{abstract}
The purpose of this study is to determine the effect of yellow watermelon juice consumption after performing anaerobic activity on blood pressure lowering, lactic acid levels and anaerobic endurance improvement. This research method is an experimental design called the randomized group pretest and post-test design. The research subjects are badminton association of Indonesia (PBSI) male athletes of Jombang branch which are randomly divided into control group (K1) and treatment group (K2), in which each consisting of 18 people. The control group is given $350 \mathrm{ml}$ syrup without sugar, while the treatment group is provided with watermelon juice of $350 \mathrm{ml}$.
\end{abstract}

Correspondence author: Afif Rusdiawan, IKIP Budi Utomo, Indonesia

Email: rusdiawan.a@gmail.com 
Anaerobic activity is carried out by sprinting 300 meters. Measurement of blood pressure, lactic acid and endurance are performed 3 times (pre, post 1 and post 2). T-test result of 2 independent samples shows the significant differences in the systolic blood pressure variable (TDS) of $p$ value $=0.023$ with $\mathrm{K} 1$ mean of $129.11 \pm 6.55 \mathrm{Mm} / \mathrm{Hg}$ and $\mathrm{K} 2$ of $125.67 \pm 4.77 \mathrm{Mm} / \mathrm{Hg}$, in diastolic blood pressure (TDD) of $p$ value $=0.019$ with $K 1$ mean of $78.72 \pm$ $4.61 \mathrm{Mm} / \mathrm{Hg}$ and $\mathrm{K} 2$ mean of $76.22 \pm 4.86 \mathrm{Mm} / \mathrm{Hg}$, in lactic acid levels of $p$ value $=0.006$ with $K 1$ mean of $4.59 \pm 0,97 \mathrm{mMol} / \mathrm{L}$ and $K 2$ mean $2.81 \pm$ $0.73 \mathrm{mMol} / L$ and in anaerobic endurance of $p$ value $=0.012$ with $K 1$ mean of $7.13 \pm 0.74$ watt / sec and K2 mean of $6.08 \pm 0.80$ watt / sec. In conclusion, yellow watermelon juice (Citrullus Vulgaris Schard) intake after performing anaerobic activity lowers blood pressure, drops lactic acid levels, and increases anaerobic endurance.

Keywords: anaerobic activity, water melon juice, blood pressure, lactic acid

\section{PENDAHULUAN}

Olahraga bulutangkis merupakan olahraga yang popular dan membanggakan bagi Indonesia karena prestasinya yang sudah mendunia. Namun akhir-akhir ini prestasi olahraga bulutangkis Indonesia mulai menurun, terbukti Indonesia terakhir meraih juara piala Thomas pada tahun 2002 dan piala uber tahun 1996. Hal ini disebabkan banyak hal, salah satunya adalah kondisi fisik yang kurang. Kondisi fisik yang kurang baik dapat diperbaiki dengan meningkatkan daya tahan dan pemulihan yang cepat (Kellmann, Bertollo, Brink, Coutts, Duffield, \& Kallus, 2018). Pemulihan atau recovery setelah latihan olahraga adalah hal penting dan dianjurkan guna mengembalikan keseimbangan fungsi tubuh pada keaadaan semula. (Astorino et al., 2011).

Salah satu penyebab kelelahan otot adalah akumulasi asam laktat dalam otot. Asam laktat yang terakumulasi akan merangsang neuromuscular-junction untuk memperingatan otak dengan rasa lelah (Allen, 2004). Kelelahan anaerobik terjadi karena aktivitas anaerobik dilakukan dengan intensitas tinggi dan membutuhkan energi cepat dan singkat untuk kontraksi (Sugiharto \& Sumartiningsih, 2013).

Purnomo (2011) menyatakan kadar asam laktat darah akan meningkat 5 menit setelah aktivitas fisik maksimal. Aktivitas fisik anaerobik akan meningkatkan produksi dan penumpukan asam laktat, yang berperan dalam munculnya kelelahan otot (Bompa \& Buzzichelli, 2015). 
Latihan dapat menyebabkan tekanan darah dan tekanan rata-rata arteri meningkat. Ketika berolahraga dengan intensitas tinggi, tekanan darah sistolik meningkat sekitar $150-200 \mathrm{mmHg}$ dari tekanan sistolik semula (istirahat) sebesar $110-120 \mathrm{mmHg}$. Tekanan darah akan menurun pada waktu 30-120 menit setelah latihan selesai dilakukan. Tekanan darah yang menurun ini akibat dari pembuluh darah yang mengalami pelebaran dan relaksasi (Rismayanthi, 2011).

Mengkonsumsi buah semangka kuning dipercaya dapat menurunkan kelelahan akibat aktivitas fisik. Buah semangka memiliki kandungan Citrulline yang dapat mengurangi kelelahan anaerobic. Citrulline adalah asam amino non esensial yang dapat mengurangi akumulasi laktat sebagai salah satu penyebab kelelahan otot (Hasanah \& Fitranti, 2015). Citrulline mempercepat proses dekomposisi asam laktat di otot sehingga asam laktat diubah menjadi glukosa lagi di hati dan ginjal melalui siklus cory (siklus laktat) (Takeda, Machida, Kohara, Omi, \& Takemasa, 2011).

Semangka juga dipercaya dapat menurunkan tekanan darah tinggi karena kandungan kalium dan citrulline-nya yang berfungsi meningkatkan kerja jantung (Figueroa, Wong, Kinsey, Kalfon, Eddy, \& Ormsbe, 2014). Citruline digunakan untuk memproduksi asam amino arginine di dalam tubuh sebagai sel-sel yang melapisi pembuluh darah untuk membuat nitrat oksida. Fungsi dari nitrat oksida adalah untuk membuat pembuluh darah menjadi rileks sehingga tekanan darah dapat diturunkan (Sari, Restipa, \& Putri, 2017).

Penelitian oleh Adnyana dkk. (2014) menyatakan bahwa ekstrak air mesokarp semangka dosis $2 \mathrm{~g} / \mathrm{kg}$ bb memiliki efek anti lelah dengan mempertahankan kadar glukosa darah, kadar glikogen hati, dan menurunkan produksi asam laktat secara bermakna (Adnyana, Arlinda, \& Safitri, 2014). Kemudian penanganan kelelahan oleh Hasanah \& Fitranti (2015) tentang perbedaan nilai kelelahan anaerobik atlet sepakbola yang diberikan buah semangka merah dan yang tidak diberikan buah semangka merah disimpulkan terdapat perbedaan nilai kelelahan 
anaerobik pada kelompok perlakuan yaitu sebesar $80,04 \%$ sedangkan pada kelompok kontrol sebesar $82,71 \%$.

Berdasarkan uraian diatas, penulis tertarik untuk meneliti efek pemberian jus semangka kuning (citrullus vulgaris schard) terhadap tekanan darah, kadar asam laktat, dan daya tahan anaerobik setelah aktivitas anaerobik.

\section{METODE}

Jenis penelitian ini adalah penelitian eksperimen dengan desain randomized group pre test and post test design.

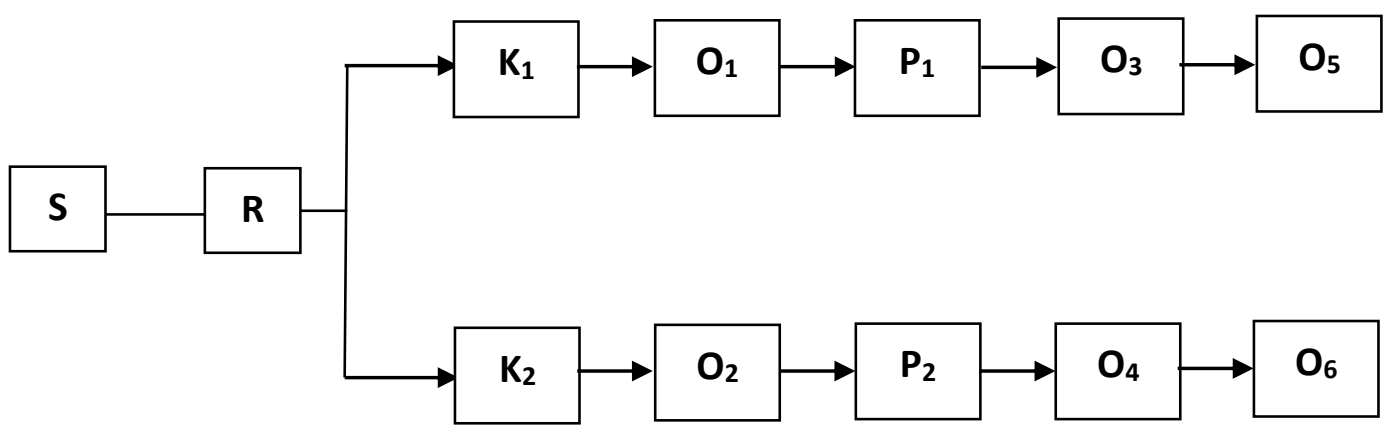

Gambar 1: Skema Rancangan Penelitian

Keterangan:

S : Sampel penelitian

R : Randomisasi

$\mathrm{K}_{1} \quad$ : Kelompok kontrol

$\mathrm{K}_{2} \quad$ : Kelompok perlakuan

$\mathrm{P}_{1} \quad$ : aktivitas anaerobik + air sirup tanpa gula $350 \mathrm{ml}$

$\mathrm{P}_{2} \quad$ : aktivitas anaerobik + semangka 350 gram

$\mathrm{O}_{1}$ : Pre test pada $\mathrm{K}_{1}$ (tekanan darah, asam laktat, daya tahan anaerobik)

$\mathrm{O}_{2}$ : Pre test pada $\mathrm{K}_{2}$ (tekanan darah, asam laktat, daya tahan anaerobik)

$\mathrm{O}_{3}$ : Post test 1 pada $\mathrm{K}_{1}$ (tekanan darah, asam laktat, daya tahan anaerobik) 
$\mathrm{O}_{4}$ : Post test 1 pada $\mathrm{K}_{2}$ (tekanan darah, asam laktat, daya tahan anaerobik)

O5 : Post test 2 pada $\mathrm{K}_{1}$ (tekanan darah, asam laktat, daya tahan anaerobik)

O6 : Post test 2 pada $\mathrm{K}_{2}$ (tekanan darah, asam laktat, daya tahan anaerobik)

Subyek penelitian ini adalah atlet bulutangkis PBSI Jombang yang berjenis kelamin laki-laki, berat badan antara $55-70 \mathrm{Kg}$, usia antara 16-20 tahun, mempunyai indeks massa tubuh (IMT) dan tekanan darah yang normal, tidak sedang dalam perawatan medis atau pascaoperasi 6 bulan sebelum penelitian, tidak sedang cedera otot yang serius, tidak mengkonsumsi minuman-minuman berenergi, tidak melakukan aktivitas fisik sebelum tes dilakukan, tidak mempunyai riwayat penyakit kardiovaskuler. Jumlah total 36 orang coba dibagi secara acak ke dalam 2 kelompok, yaitu kelompok control (K1) dan kelompok perlakuan (K2) yang masing- masing terdiri dari 18 orang coba.

Pengambilan data penelitian berupa kadar asam laktat, tekanan darah dan daya tahan anaerobic dilakukan di GOR merdeka Jombang. Pengukuran tekanan darah menggunakan tensimeter digital merk Omron HEM-7130 buatan Jepang tahun 2016. Pengukuran tekanan darah dilakukan sebanyak 3 kali yaitu sebelum perlakuan (pretest), segera setelah aktivitas anaerobik (posttest 1) dan 15 menit setelah konsumsi jus semangka maupun placebo (posttest 2).

Pengukuran asam laktat menggunakan laktat meter dengan merk Roche Cobas Accutrend Plus GCTL Meter buatan Jerman tahun 2017. Asam laktat diukur sebanyak 3 kali yaitu sebelum perlakuan (pretest), segera setelah aktivitas anaerobik (posttest 1) dan 1 jam setelah konsumsi jus semangka maupun placebo (posttest 2).

Pengukuran daya tahan anaerobik menggunakan Uji RAST (Running-based Anaerobic Sprint Test) (Adamczyk, 2011). Daya tahan anaerobik diukur sebanyak 3 kali yaitu sebelum perlakuan (pretest), 
segera setelah aktivitas anaerobik (posttest 1) dan 1 jam setelah konsumsi jus semangka maupun placebo (posttest 2). Uji RAST dihitung menggunakan rumus:

Indeks Kelelahan $=\frac{\text { powver maksimal }- \text { power minimal }}{\text { Total waktu dari } 6 \mathrm{x} \text { sprint }}$

Sebelum pengambilan data, subjek penelitian diminta untuk puasa selama 8 jam dengan tetap mengkonsumsi air mineral. Berikutnya adalah pengambilan data tes awal (pretest) yaitu dengan mengukur tekanan darah, kadar asam laktat dan daya tahan anaerobik. Setelah 30 menit, berikutnya melakukan aktivitas anaerobik berupa lari sprint sepanjang 300 meter (Harahap, Pahutar, \& Pendahuluan, 2017). Selanjutnya, diukur kembali tekanan darah, kadar asam laktat, dan daya tahan anaerobik untuk data posttest 1 . Segera setelah posttest 1, subyek penelitian diberikan $350 \mathrm{ml}$ air sirup tanpa gula untuk kelompok control dan $350 \mathrm{ml}$ jus semangka untuk kelompok perlakuan (Sirait et al., 2015; Caturwati, Bintanah, \& Kusuma, 2015). 15 menit setelah diberikan air sirup maupun jus semangka, subjek penelitian diukur tekanan darahnya (Andi, Afriwardi, \& Detty, 2016) Kemudian 60 menit setelah diberikan air sirup maupun jus semangka, subjek penelitian diukur kadar asam laktat darahnya dan daya tahan anaerobiknya (post test 2) (Purnomo, 2011; Hasanah \& Fitranti, 2015). Analisis data dilakukan dengan bantuan program SPSS seri 20 (uji deskriptif, uji normalitas dan uji t2 sampel bebas).

\section{HASIL}

\section{Hasil Analisis Deskriptif Sampel}

Hasil analisis deskriptif sampel penelitian disajikan pada tabel 1.

Tabel 1. Rerata dan Standart deviasi (SD) Usia, Tinggi Badan, Berat Badan dan Indeks Massa Tubuh (IMT) Sampel Penelitian

\begin{tabular}{ccccc}
\hline Kelompok & \multicolumn{4}{c}{ Rerata \pm SD Usia, TB, BB dan IMT } \\
\cline { 2 - 5 } & Usia (tahun) & TB (cm) & BB (kg) & IMT \\
\hline Kontrol & $18,44 \pm 1,29$ & $168,89 \pm 2,81$ & $59,89 \pm 4,79$ & $20,97 \pm 1,19$ \\
\hline Perlakuan & $17,78 \pm 1,35$ & $167,00 \pm 4,56$ & $62,61 \pm 4,58$ & $22,47 \pm 1,67$ \\
\hline
\end{tabular}


Dari hasil analisis deskriptif sampel penelitian didapatkan hasil sesuai dengan kriteria pada kedua kelompok yaitu usia 16-20 tahun, data berat badan 55-70 tahun, indeks massa tubuh (IMT) normal 18,5-24,9.

\section{Hasil Analisis Deskriptif Tekanan Darah}

Hasil analisis deskriptif tekanan darah systole disajikan pada tabel 2 berikut:

Tabel 2. Rerata dan Standart Deviasi (SD) Tekanan Darah Systole (TDS)

\begin{tabular}{cccc}
\hline Kelompok & \multicolumn{3}{c}{ Rerata \pm SD Tekanan darah $(\mathrm{Mm} / \mathrm{Hg})$} \\
\cline { 2 - 4 } & Pystole \\
\cline { 2 - 4 } & Pretest & Posttest 1 & Posttest 2 \\
\hline Kontrol & $118,06 \pm 6,69$ & $155,61 \pm 5,34$ & $129,11 \pm 6,55$ \\
\hline Perlakuan & $119,28 \pm 8,26$ & $156,00 \pm 5,65$ & $125,67 \pm 4,77$ \\
\hline
\end{tabular}

Keterangan:

Pretest = sebelum perlakuan

Posttest 1 = setelah aktivitas anaerobik dan sebelum konsumsi jus semangka atau placebo

Posttest 2 = setelah aktivitas anaerobik dan konsumsi jus semangka atau kontrol

Dari analisis deskriptif tekanan darah systole didapatkan nilai postest 1 yang meningkat dari nilai pretest pada kedua kelompok. Namun pada posttest 2 didapatkan nilai yang menurun dari posttest 1 . Berikut diagram perbedaan data rerata tekanan darah systole antara pretest, posttest 1 dan posttest 2 antar kelompok.

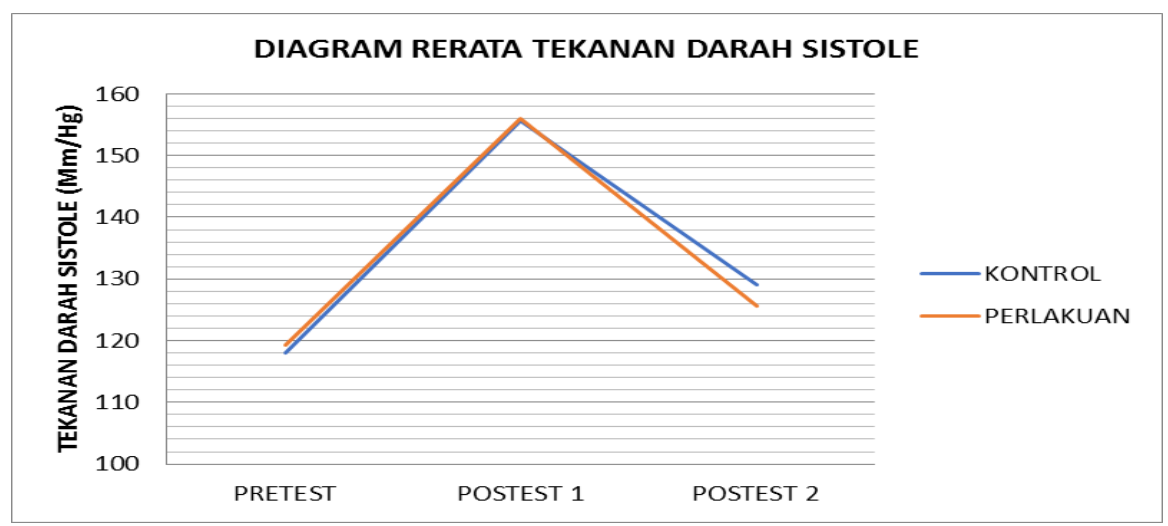

Gambar 2. Diagram Garis Rerata Tekanan Darah Sistole Pretest, Posttest 1 dan Posttest 2 antar Kelompok 
Analisis deskriptif tekanan darah diastole disajikan pada tabel 3:

Tabel 3. Rerata dan Standart deviasi (SD) Tekanan Darah Diastole (TDD)

\begin{tabular}{cccc}
\hline Kelompok & \multicolumn{3}{c}{ Rerata \pm SD Tekanan darah $(\mathbf{M m} / \mathbf{H g})$} \\
\cline { 2 - 4 } & Pretest & Posttest 1 & Posttest 2 \\
\cline { 2 - 4 } & Priastole & $78,72 \pm 4,61$ \\
\hline Kontrol & $74,39 \pm 5,17$ & $84,56 \pm 5,26$ & $76,22 \pm 4,86$ \\
\hline Perlakuan & $72,56 \pm 5,28$ & $85,06 \pm 4,39$ &
\end{tabular}

Berikut diagram garis perbedaan data rerata tekanan darah diastole antara pretest, posttest 1 dan posttest 2 antar kelompok.

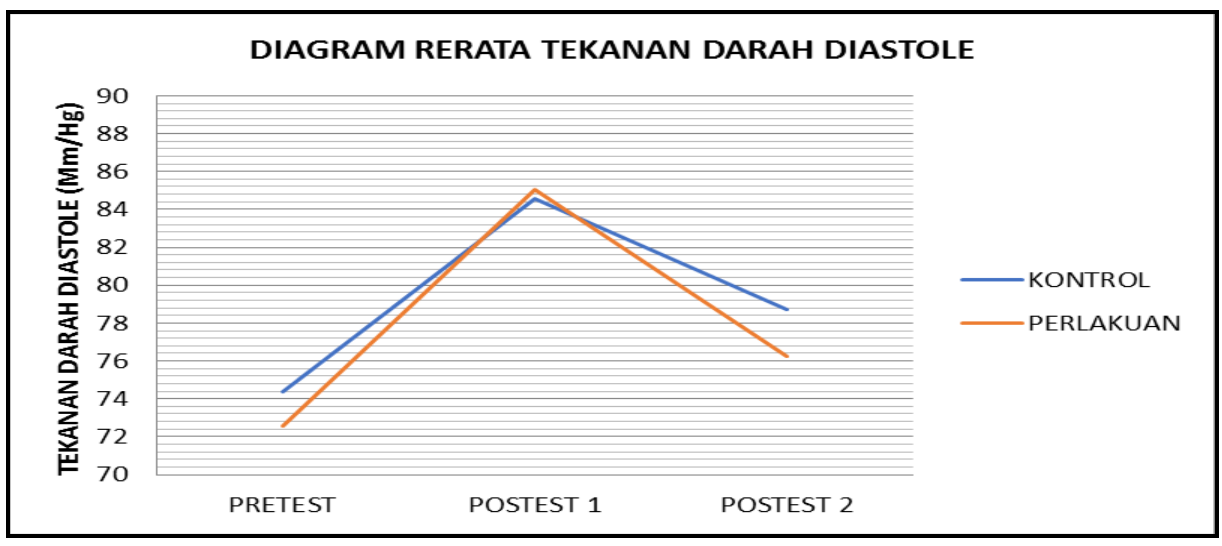

Gambar 3. Diagram Garis Rerata Tekanan Darah Diastole

\section{Hasil Analisis Deskriptif Asam Laktat}

Hasil analisis deskriptif kadar asam laktat disajikan pada tabel 4 berikut:

Tabel 4. Rerata $\pm S D$ Kadar Asam Laktat

\begin{tabular}{|c|c|c|c|}
\hline \multirow[t]{2}{*}{ Kelompok } & \multicolumn{3}{|c|}{ Rerata $\pm S D$ kadar asam laktat (mMol/L) } \\
\hline & Pretest & Posttest 1 & Posttest 2 \\
\hline Kontrol & $1,19 \pm 0,58$ & $8,78 \pm 1,18$ & $4,59 \pm 0,97$ \\
\hline Perlakuan & $1,21 \pm 0,35$ & $8,18 \pm 1,21$ & $2,81 \pm 0,73$ \\
\hline
\end{tabular}

Berikut diagram garis perbedaan data rerata asam laktat antara pretest, posttest 1 dan posttest 1 antar kelompok. 


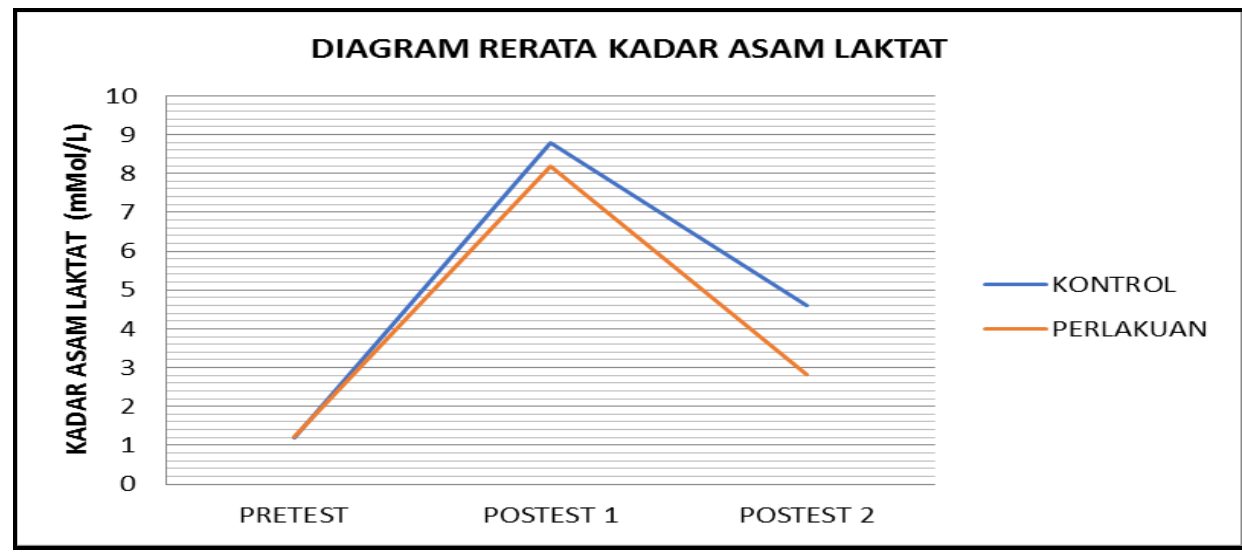

Gambar 4. Diagram Garis Rerata Kadar Asam Laktat Pretest, Posttest 1 dan Posttest 1 antar Kelompok

\section{Hasil Analisis Deskriptif Daya Tahan Anaerobik}

Hasil analisis deskriptif daya tahan anaerobik disajikan pada tabel 5 berikut:

Tabel 5. Rerata $\pm S D$ Daya Tahan Anaerobik

\begin{tabular}{cccc}
\hline Kelompok & \multicolumn{3}{c}{ Rerata \pm SD } \\
& Daya Tahan Anaerobik & (Watt/Sec) \\
\cline { 2 - 4 } & Pretest & Posttest 1 & Posttest 2 \\
\hline Kontrol & $3,89 \pm 1,20$ & $8,60 \pm 0,93$ & $7,13 \pm 0,74$ \\
\hline Perlakuan & $4,09 \pm 1,23$ & $8,72 \pm 0,97$ & $6,08 \pm 0,80$ \\
\hline
\end{tabular}

Berikut diagram garis perbedaan data rerata keleahan anaerobik antara pretest, posttest 1 dan posttest 2 antar kelompok.

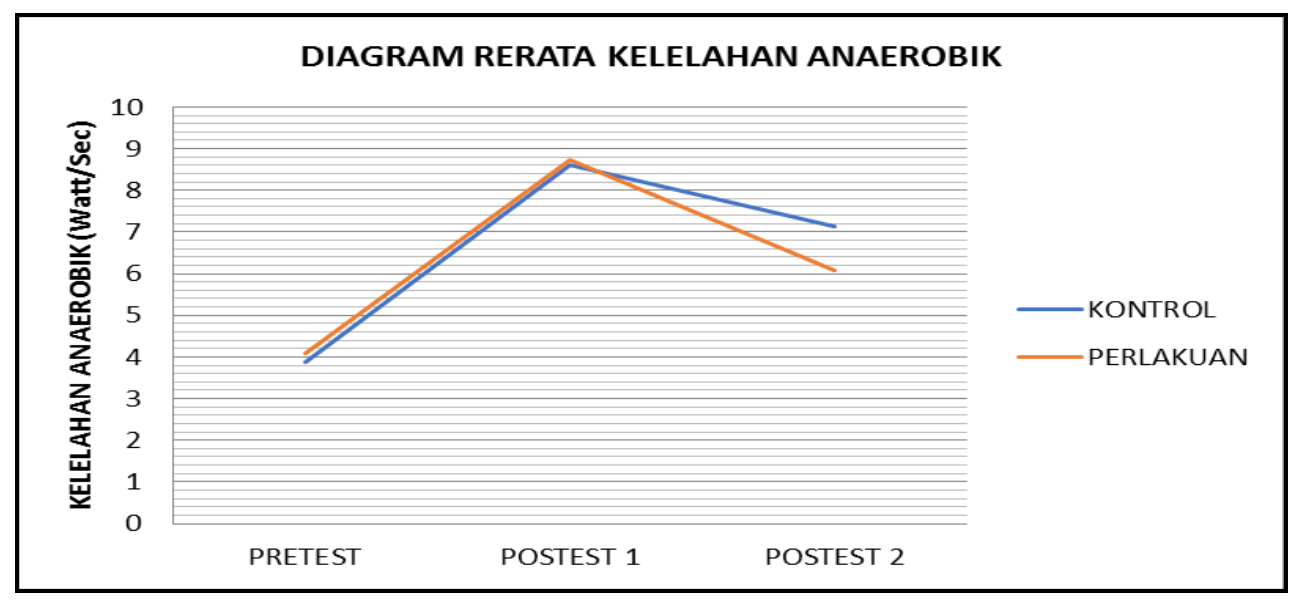

Gambar 5. Diagram Garis Rerata Daya Tahan Anaerobik Pretest, Posttest 1 dan Posttest 2 antar Kelompok 


\section{Hasil Uji Normalitas}

Hasil uji normalitas menggunakan uji kolmogorov smirnov pada semua variable dan kelompok menunjukkan data yang berdistribusi normal dengan nilai $p>0,05$. Sehingga dapat dilanjutkan menggunakan uji t2 sampel bebas.

\section{Hasil Uji T2 Sampel Bebas}

Hasil uji t 2 sampel bebas dapat dilihat pada table 10 di bawah ini.

Tabel 6. Hasil uji t 2 sampel bebas semua variabel

\begin{tabular}{|c|c|c|c|c|}
\hline Kelompok & TDS & TDD & Asam laktat & $\begin{array}{c}\text { Daya Tahan } \\
\text { Anaerobik }\end{array}$ \\
\hline post1-post2 & $0,023^{*}$ & $0,019^{*}$ & $0,006^{*}$ & $0,012^{*}$ \\
\hline
\end{tabular}

Hasil uji t 2 sampel bebas menunjukkan nilai $p<0,05$ pada semua variable. Hal tersebut dapat disimpulkan bahwa terdapat perbedaan yang bermakna antara kelompok kontrol dan perlakuan pada semua variabel.

\section{PEMBAHASAN}

\section{Pemberian Jus Semangka Kuning (Citrullus Vulgaris Schard) Terhadap Tekanan Darah Setelah Aktivitas Anaerobik}

Respon terhadap fisiologis akibat aktivitas olahraga adalah meningkatnya distribusi oksigen melalui darah ke bagian tubuh yang membutuhkan sehingga curah jantung juga meningkat. Respon kardiovaskuler pada latihan olahraga dengan intensitas tinggi dapat meningkatkan tekanan darah dan tekanan rata-rata arteri. Saat latihan fisik berat, tekanan darah sistolik (TDS) dapat meningkat menjadi 150 $200 \mathrm{mmHg}$ dari tekanan sistolik saat istirahat sekitar $110-120 \mathrm{mmHg}$. Tekanan darah akan berangsur turun i selama 30-120 menit setelah latihan selesai. Penurunan ini terjadi akibat pelebaran dan relaksasi pembuluh darah (Manansang, Rumampuk, \& Moningka, 2018).

Hasil analisis deskriptif pada tabel 2 dan tabel 3 menunjukkan peningkatan tekanan darah baik systole maupun diastole setelah aktivitas anaerobik pada kedua kelompok (posttest 1). Hal tersebut dikarenakan saat beraktivitas fisik, kebutuhan tubuh akan $\mathrm{O}_{2}$ semakin banyak akibat 
dari peningkatan metabolisme sel untuk menghasilkan sumber energi. Akibatnya adalah pendistribusian darah akan semakin cepat dan jumlah darah yang dibutuhkan juga akan semakin besar. Otot jantung dan otot rangka mengalami vasodilatasi sedangkan arteriol mengalami vasokontriksi sehingga menyebabkan kerja jantung tiap satuan waktu meningkat dan volume darah arteriol juga meningkat serta tekanan darahpun meningkat. Hal ini berarti bahwa volume darah yang masuk dari arteri menuju jantung meningkat. Persentase darah yang dialirkan ke organ-organ yang aktif untuk aktivitas fisik lebih tinggi daripada organorgan lain seperti ginjal dan saluran pencernaan (Handyani, Lintong, Fransiska, \& Rumampuk, 2016)

Kemudian hasil posttest 2 menunjukkan hasil yang menurun pada kedua kelompok (lihat gambar 2 untuk sistol dan 3 untuk diastole). Namun nilai penurunan tekanan darah antara kelompok kontrol dan kelompok perlakuan berbeda (tabel 6). Semangka (Citrullus vulgaris) merupakan buah yang dapat digunakan untuk mencegah penyakit hipertensi ataupun menurunkan tekanan darah. Semangka mengandung sitrulin, air, kalium, vitamin C, vitamin A (karotenoid), dan vitamin $\mathrm{K}$, sehingga buah semangka dapat digunakan untuk mengobati penyakit hipertensi (Manurung et al., 2016).

Meningkatnya asupan kalium karena konsumsi semangka mempunyai hubungan dengan penurunan tekanan darah, karena kalium memicu natriuresis (kehilangan natrium melalui urin) (Pardede \& Murti, 2010). Efek natrium akan menurun akibat kandungan kalium pada semangka sehingga tekanan darah juga menurun. Kalium berfungsi menjaga kekentalan darah agar tetap stabil. Hubungan antara kalium dan natrium yang berbanding terbalik inilah yang menjelaskan bagaimana tekanan darah dapat menurun baik tekanan sistolik maupun diastolik. Kalium menyebabkan vasodilatasi pembuluh darah sehingga menurunkan tekanan darah. Selain itu, kalium bekerja menghambat proses konversi renin menjadi renin-angiotensin melalui hambatan enzim angiotensin 
(angiotensin converting enzym inhibitor) sehingga tekanan darah tidak meningkat (Solihah, 2015)

Semangka juga mengandung Lycopein yang tinggi. Fungsi lycopein adalah sebagai anti oksidan dan efek diuretik yang bisa menyebabkan pembuluh darah menjadi lentur sehingga sirkulasi darah ke seluruh tubuh lancar dan pada akhirnya tekanan darah menurun (Manurung et al., 2016).

\section{Pemberian Jus Semangka Kuning (Citrullus Vulgaris Schard)}

\section{Terhadap Kadar Asam Laktat Setelah Aktivitas Anaerobik}

Hasil analisis deskriptif pada tabel 4 menunjukkan peningkatan kadar asam laktat setelah aktivitas anaerobic pada kedua kelompok (posttest 1). Saat beraktivitas fisik, tubuh meningkatkan metabolismenya untuk menghasilkan energy dalam kontraksi otot. Asam laktat terbentuk akibat latihan dengan intensitas tinggi dan dalam waktu yang lama. Semakin tinggi intensitas latihan atau aktivitas fisik, maka semakin tinggi tingkat metabolisme tubuh dan proses metabolisme akan semakin bergeser ke arah anaerobik (glikolisis anaerobik) (Purnomo, 2011). Peningkatan kadar asam laktat akibat aktivitas fisik akan menurunkan $\mathrm{pH}$ di dalam sel. Kadar $\mathrm{pH}$ yang menurun akan menurunkan produksi ATP akibat gangguan kinerja enzim (Gibson \& Noakes, 2004).

Kemudian hasil posttest 2 menunjukkan hasil yang menurun pada kedua kelompok (lihat gambar 4 dan tabel 6). Menurunnya kadar asam laktat yang lebih cepat dengan pemberian jus semangka kuning ini sesuai dengan penelitian oleh Tarazona-Díaz, Alacid, Carrasco, Martínez, \& Aguayo (2013) yang menyatakan bahwa kandungan citrulline dalam jus semangka kuning (citrullus vulgaris schard) mampu mempercepat pemulihan otot dengan menguraikan asam laktat.

Citrulline termasuk ke dalam golongan asam amino non esensial. Dalam buah semangka terdapat kandungan citrulline sebesar $160 \mathrm{mg}$ citrulline per $100 \mathrm{gr}$ semangka. Citrulline dapat mengurangi penumpukan asam laktat dari metabolisme anaerobik (Rizal \& Segalita, 2018). 
Citrulline menguraikan asam laktat otot di hati dan ginjal lebih cepat melalui siklus cory untuk diubah menjadi energi. Citrulline juga dapat mendetoksifikasi zat amonia di dalam hati bersamaan dengan asam amino lainnya. Zat Amonia bekerja mengaktifkan fosfofruktokinase yang membantu dalam proses produksi asam laktat. Kadar amonia yang meningkat akan menyebabkan peningkatan kadar asam laktat yang menyebabkan kelelahan (López-cabral \& Sánchez-gonzález, 2012).

\section{Pemberian Jus Semangka Kuning (Citrullus Vulgaris Schard)} Terhadap Daya Tahan Anaerobik Setelah Aktivitas Anaerobik

Hasil analisis deskriptif pada tabel 5 menunjukkan peningkatan nilai kelelahan anaerobik setelah aktivitas anaerobik pada kedua kelompok (posttest 1). Hal tersebut dikarenakan saat beraktivitas fisik anaerobik, asam laktat diproduksi sehingga mengalami akumulasi dan menyebabkan kelelahan. Variabel daya tahan dapat dilihat dengan nilai indeks kelelahan anaerobic. Semakin rendah nilai indeks kelelahan anaerobiknya, maka semakin baik daya tahan anaerobiknya.

Kemudian hasil posttest 2 menunjukkan hasil yang menurun pada kedua kelompok (lihat gambar 5 dan tabel 6). Kandungan citrulline dalam semangka memiliki peran meningkatkan performa dalam olahraga dengan menunda kelelahan (Rizal, Segalita, \& Mahmudiono, 2019). Citrulline membantu terbentuknya nitrit oksida yang menyebabkan aliran darah meningkat sehingga dapat membuang produk sampingan dari metabolisme anaerobik. Selain itu, citrulline juga mampu mendetoksifikasi zat amonia di dalam hati yang merupakan penghasil asam laktat berlebihan yang dapat menyebabkan kelelahan. Pemberian citrulline dengan mengkonsumsi semangka selama 7 hari maupun hanya sekali serta dilakukan satu jam sebelum dilakukan aktivitas fisik diketahui dapat meningkatkan VO2max, mengurangi rasa nyeri otot serta menunda kelelahan otot setelah latihan (Rizal \& Segalita, 2018).

\section{KESIMPULAN}

Pemberian jus semangka kuning (citrullus vulgaris schard) dapat meningkatkan performa olahraga khususnya tipe anaerobik dengan 
mempercepat pemulihan baik tekanan darah, kadar asam laktat, dan daya tahan anaerobic. Hasil penelitian ini agar digunakan oleh para pelatih guna meningkatkan performa atletnya terutama olahraga tipe anaerobic. Untuk dapat mengetahui mekanisme pengaruh semangka khususnya kandungan sitrulinnya lebih mendalam, maka perlu penelitian lebih lanjut pengaruh semangka pada tingkat metabolism seluler.

\section{UCAPAN TERIMA KASIH}

Ucapan terima kasih kepada PBSI Jombang yang telah mengizinkan penelitian ini. Kemudian ucapan terima kasih ditujukan juga kepada DRPM Kemenristekdikti yang telah memberikan dana untuk penelitian ini serta pihak - pihak lain yang telah membantu penelitian ini.

\section{REFERENSI}

Adamczyk, J. (2011). The estimation of the RAST test usefulness in monitoring the anaerobic capacity of sprinters in athletics. Polish Journal of Sport and Tourism, 18(3), 214-218.

Adnyana, I. K., Arlinda, N. D., \& Safitri, D. (2014). Efek Antilelah Ekstrak Air Mesokarp Semangka Kuning (Citrullus lanatus Thunb.) Tanpa Biji. Kartika Jurnal Ilmiah Farmasi, 2(2), 1-6. https://doi.org/10.26874/kjif.v2i2.27

Allen, T. J. (2004). Textbook of Work Physiology: Physiological Bases of Exercise, Fourth Edition. Physiotherapy Canada, 56(4), 248. https://doi.org/10.2310/6640.2004.00030

Andi, A., Afriwardi, \& Detty, I. (2016). Gambaran Perubahan Tekanan Darah Pasca Olahraga Futsal pada Mahasiswa Fakultas Kedokteran Universitas Andalas. Jurnal Kesehatan Andalas., 5(2), 319-324.

Astorino, T., Baker, J., Brock, S., Dalleck, L., Goulet, E., Gotshall, R., \& Lim, Y. A. (2011). Muscle recovery after a session of resistance training monitored through serum creatine kinase. Journal of Exercise Physiologyonline, 14(5).

Bompa, T., \& Buzzichelli, C. (2015). Periodization Training for Sports-3rd Edition. Retrieved from https://books.google.com/books?id=Zb7GoAEACAAJ\&pgis=1

Caturwati, I., Bintanah, S., \& Kusuma, H. S. (2015). Pengaruh variasi dosis semangka kuning (citrullus vulgaris schard) terhadap tekanan darah lansia di panti wredha bala keselamatan Bugangan Semarang. Jurnal Gizi, 4(2). 
Figueroa, A., Wong, A., Kinsey, A., Kalfon, R., Eddy, W., \& Ormsbee, M. J. (2014). Effects of milk proteins and combined exercise training on aortic hemodynamics and arterial stiffness in young obese women with high blood pressure. American journal of hypertension, 27(3), 338-344.

Gibson, A. S. C., \& Noakes, T. D. (2004). Evidence for complex system integration and dynamic neural regulation of skeletal muscle recruitment during exercise in humans. British journal of sports medicine, 38(6), 797-806. https://doi.org/10.1136/bjsm.2003.009852

Handayani, G., Lintong, F., \& Rumampuk, J. F. (2016). Pengaruh Aktivitas Berlari Terhadap Tekanan Darah dan Suhu Pada Pria Dewasa Normal. eBiomedik, 4(1).

Harahap, N. S., \& Pahutar, U. P. (2017). Pengaruh Aktivitas Fisik Aerobik dan Anaerobik Terhadap Jumlah Leukosit Pada Mahasiswa IImu Keolahragaan Universitas Negeri Medan. Sains Olahraga: Jurnal IImiah IImu Keolahragaan, 1(2), 96-104.

Hasanah, U., \& Fitranti, D. Y. (2015). Perbedaan Nilai Kelelahan Anaerobik Atlet Sepakbola Yang Diberikan Buah Semangka Merah Dan Tidak Diberikan Buah Semangka Merah (Citrullus Lanatus) (Doctoral dissertation, Diponegoro University).

Kellmann, M., Bertollo, M., Bosquet, L., Brink, M., Coutts, A. J., Duffield, R., \& Kallus, K. W. (2018). Recovery and performance in sport: consensus statement. Int J Sports Physiol Perform, 13(2), 240-245.

Lone, V., Ardiaria, M., \& Nissa, C. (2017). Perbedaan Efektivitas Pemberian Pisang Raja Dan Pisang Ambon Terhadap Indeks Kelelahan Otot Anaerobik Pada Remaja Di Sekolah Sepak Bola. Journal of Nutrition College, 6(4), 350-356. https://doi.org/10.14710/jnc.v6i4.18787

López-cabral, J. A., \& Sánchez-gonzález, J. M. (2012). Modification of fatigue indicators using citrulline malate for high. Rev Latinoamer Patol Clin, 59(4), 194-201.

Manansang, G. R., Rumampuk, J. F., \& Moningka, M. E. W. (2018). Perbandingan Tekanan Darah Sebelum dan Sesudah Olahraga Angkat Berat. Jurnal E-Biomedik, 6(2). https://doi.org/10.35790/ebm.6.2.2018.21585

Manurung, W. P., \& Wibowo, A. (2016). Pengaruh Konsumsi Semangka (Citrullus vulgaris) untuk Menurunkan Tekanan Darah pada Penderita Hipertensi. Jurnal Majority, 5(5), 102-107.

Pardede, T. R., \& Muftri, S. (2010). Penetapan kadar kalium, natrium dan magnesium pada semangka (citrullus vulgaris, schard) daging buah berwarna kuning dan merah secara spektrofotometri serapan atom. 
Jurnal Darma Agung, 2(1), 1-7.

Purnomo, M. (2011). Asam Laktat dan Aktivitas SOD Eritrosit pada Fase Pemulihan Setelah Latihan Submaksimal. Jurnal Media ilmu Keolahragaan, 1(2), 155-170.

Rismayanthi, C. (2011). Penurunan tekanan darah pada penderita hipertensi melalui senam aerobik low impact. Medikora, VII(1), 1326. https://doi.org/10.21831/medikora.v0i1.4657

Rizal, M., \& Segalita, C. (2018). Peran Asam Amino Sitrulin dalam Meningkatkan Performa Olahraga Pada Atlet The Role of Amino Acid Citrulline in Improving Sports Performance Among Athletes. 299306. https://doi.org/10.20473/amnt.v2.i4.2018.299-306

Sari, R. P., Restipa, L., \& Putri, M. Y. (2017). Pengaruh Pemberian Jus Semangka Terhadap Penurunan Tekanan Darah Pada Lansia Penderita Hipertensi Di Wilayah Kerja Puskesmas Lubuk Buaya Padang Tahun 2017. JIK (JURNAL ILMU KESEHATAN), 1(1), 79-86.

Sirait, P. A., Abrori, C., \& Suswati, E. (2016). Pengaruh Pemberian Jus Semangka terhadap Kelelahan Otot dan Delayed Onset Muscle Soreness setelah Latihan Beban (The effect of Watermelon Juice on Muscle Fatigue and Delayed Onset Muscle Soreness after Weight Training). Pustaka Kesehatan, 4(1), 132-135.

Solihah, Z. (2015). Studi Komparasi Pemberian Buah Semangka Dan Buah Melon Terhadap Tekanan Darah Pada Lansia Hipertensi Di Dusun Pundung Sleman Yogyakarta. https://doi.org/10.1017/CBO9781107415324.004

Sugiharto, \& Sumartiningsih, S. (2013). Penurunan Asam Laktat pada Fase Pemulihan Aktif dengan Argocycle selama 5 Menit. Media IImu Keolahragaan https://doi.org/10.15294/miki.v2i1.2555

2(1).

Takeda, K., Machida, M., Kohara, A., Omi, N., \& Takemasa, T. (2011). Effects of citrulline supplementation on fatigue and exercise performance in mice. Journal of Nutritional Science and Vitaminology, 57(3), 246-250. Retrieved from http://www.ncbi.nlm.nih.gov/pubmed/21908948

Tarazona-Díaz, M. P., Alacid, F., Carrasco, M., Martínez, I., \& Aguayo, E. (2013). Watermelon juice: potential functional drink for sore muscle relief in athletes. Journal of agricultural and food chemistry, 61(31), 7522-7528. 